\title{
The Strategy of Street Vendors in Facing Local Government Policy. A Case of Street Vendor in Bandung
}

\author{
Rina Hermawati* \\ Department of Anthropology, Faculty of Social and Political Science, Universitas Padjadjaran, Indonesia
}

\begin{abstract}
Objective - The presence of street vendors in public places has emerged some problems, such as disordered situation, traffic jam and decreasing aesthetics of the city. In order to overcome the problems, Bandung have some policies issued such as relocation, arrangement and business loans. However, these policies never completely solve the street vendors problems. This research will describe the strategy of street vendors in retaining the existence of their selling place.

Methodology/Technique - The research took place in Bandung using the qualitative approach. Bandung is one of the big city in Indonesia and also capital of west java province. The activity of data collection was conducted through participant observation, in-depth interviews, and documentation.

Findings - The result of the research shows that the strategy of street vendors in resisting the city government was conducted through various ways, both disguised and open ones. Both types of resistance were committed individually and collectively.

Novelty - This article describes the tactics and strategies developed by the street vendors to face the government policy. Type of Paper: Empirical
\end{abstract}

Keywords: Street Vendors; Public Places; Public Policy; Resistance; Relocation.

JEL Classification: P25, J48.

\section{Introduction}

The informal economy sector is a phenomenon that easily found in big cities in Indonesia. The problem of urbanization which is not equaled by the expansion of employment opportunities in the formal sector has also contributed to the growth of the informal economy sector (Manning \& Effendi, 1991; Rachbini \& Hamid, 1994).

Among many occupations in the informal sector, one with the most dominant and prominent activities is the street vendor. The presence of huge numbers of street vendors has dominated the fulfillment of the needs of city residents, especially the lower middle class. Besides that, the street vendor is also a type of business of the informal sector which is often affected by government policy (Rachbini \& Hamid, 1994). It cannot be separated from the business characteristic of street vendors, which utilizes public places as their selling places.

\footnotetext{
* Paper Info: Received: January 19, 2017

Accepted: March 13, 2017

* Corresponding author:

E-mail: rina.antrop@gmail.com

Affiliation: Faculty of Social and Political Science, Universitas Padjadjaran, Indonesia.
} 
The presence of street vendors in public places has become a factor that causes a disordered situation, traffic jam, a decreasing function of the sidewalk, the diminishing beauty of the city, and social tensions. As a result, street vendors frequently become the main target of the eviction and relocation program by the government. However, the eviction and relocation program never completely settled the problem of street vendors. Although street vendors are frequently targeted to be ordered, regulated, and arranged, their presence continues to become a trend and they still thrive and even increasingly flourish.

This condition indicates that street vendors are not merely the object of power that obeys the government policy, but they develop various tactics and strategies to face the government policy. In other words, street vendors are not only the object of power but also the subject of power. Based on the elaboration above, this article describes the tactics and strategies developed by the street vendors to face the government policy.

\section{Literature Review}

Government policy on street vendors is an effort to regulate and to control their presence in public places. By using the policy, the government has classified the places which are allowed and not allowed to be used as selling places, which is, of course, different from the interpretation of street vendors in public places. That is so because the government interprets spaces by using the perspective of control and also the orderliness, beautification, and comfort of the city, while the street vendors use the perspective of the economy. To retain their interest in public places, street vendors have used some tactics which aim to undermine the government policy, including the government institution.

The elaboration above shows that actually the policy cannot be separated from the issue of power (Hansen 1999). In this case, policy can be defined as the way of the government plays power through policies. However, these power must be understood in an unconventional way, or as it proposed by Angela Cheater in her writing "Power in the Postmodern Era". Cheater stated that the conception of power in the postmodern era is very different from the thoughts of Weber's followers who separated power (as the ability to elicit compliance) and authority (as the right to expect compliance). However, Foucault himself, as quoted by Cheater (1999:3), apparently did not distinguish between power and authority because ordinary individuals can also carry out the power.

"Individuals... are always in the position of simultaneously undergoing and exercising this power. They are not only its inert or consenting target; they are always also the elements of its articulation......the vehicles of power, not its points of application".

Therefore power, based on this understanding, is not only played by the state, but also by individuals. The individuals, who are expected to be the target of the policy, will undoubtedly give resistances by or through the power they can play. That is why Abu-Lughod (1989) -by quoting Foucault who said 'where there is power, there is resistance'-could say that resistance is a diagnostic of power.

Scott in his book, Weapons of the Weak (2000) has explained that the resistance of the lower class residents is any act(s) by member(s) of the class that is (are) intended either to mitigate or to deny claims (e.g. rents, taxes, deference) made on that class by superordinate classes (e.g. landlords, the state, owners of machinery, moneylenders) or to advance its own claims (e.g. to work, land, charity, respect) vis-a-vis these superordinate classes. These forms of resistance vary either the open resistance (acts that have direct connection to the officials) such as opposing the officials or the covert resistance (avoiding direct contact with the officials) such as gossiping, libeling, complaining, grumbling, pretending to be obedient, et cetera.

Based on the discussion above, the government carry out their power to set street vendors through the policy about street vendors. On the other hand, street vendors have run their power by doing resistances as an effort to weaken the government policy. The attraction between the government and street vendors could be the root cause of the difficulty to solve the street vendors problem. 


\section{Research Method}

The research took place in Bandung using the qualitative approach. Bandung is one of the big city in Indonesia and also the capital of west java province. The activity of data collection was conducted through participant observation, in-depth interviews, and documentation.

Participant observation was conducted to find out directly about selling activities of street vendors, the situation and interaction they have built and also tactics and strategies they have developed to fight for their selling places. The interviews were purposively conducted with street vendors, board members of the association of street vendors and the city government. In topics outline, the questions are about street vendors' attitude towards the government policies (eviction, relocation, arrangement and supervision) and street vendors' action against the policies.

Meanwhile, documentation materials used for this research particularly relate to characteristics and distribution of street vendors, an organization of street vendors, activities of the city government deal with Street Vendors and strategies of Street Vendors deal with the policies of the city government. These documents were obtained from government, an association of street vendors, the Internet, blogs, photos, videos and other literature.

\section{Findings}

\subsection{General Description of Street Vendors in Bandung}

Year by year the number of street vendors in Bandung is growing significantly, particularly after the monetary crisis of 1988 which resulted in the difficulty in finding jobs in the formal sector and a huge number of dismissed laborers. It shows that the lack of employment opportunities in the formal sector has become the driving factor to the thriving of the business of street vendors. This finding affirms another study that stated street vendors as the field of work and the safety valve of urban economies (Ramli, 1992; Rachbini, 1994).

Selling activities of street vendors are affected by formal activities of the surroundings, whether those relate to the location, the distribution pattern, characteristics of the services, kinds of goods they sell or their selling hours. It is not surprising that they are easily found around the activities of the formal sector, such as offices, shopping centers (malls), campuses, schools, sports grounds, and other public places. In this case, the informal and formal sectors are complementary to each other (McGee, 1973, Wirahadikusuma, 1991; Swasono in Rachbini, 1994), in which the growth of the formal sector will bring about the selling activities of street vendors. The presence of street vendors is needed by the formal sector to provide it with cheap goods and services and to distribute the goods produced by the formal sector, such as drinks, foods, newspapers, cigarettes, et cetera.

Socio-economic characteristics of street vendors, viewed in terms of levels of education, income and business typology, are increasingly varying. Before the monetary crisis of 1988 , characteristics of street vendors met the following criterion: having a lower education level, migrant residents, having a small capital, having uncertain working hours and income, using mats/tables as their means of business, with the lower middle class as the consumer target. Then, after the monetary crisis of 1998, we began finding street vendors who had a higher education (high schools and universities), big capital, high income, and modern means of business, such as motorcycles and cars. In the same way, consumers of street vendors now also come from the middle class through high-quality products at a quite expensive price (hundreds to millions of rupiahs). This phenomenon indicates that the studies which view the business of street vendors as a small-scale business and identical to the urban poor group (Sethurahman, 1981; Firdausy, 1995) are not fully relevant now. The changes of the characteristics of street vendors are similar to the finding of Maneepong and Walsh (2013) which describes the presence of a new generation of street vendors in Bangkok. 


\subsection{Policies of the City Government of Bandung on the Presence of Sidewalk Vendors}

Although street vendors have existed since the 1960s, the City Government of Bandung did not issue a policy on them. It was not until 2005 that the city government issued a policy on street vendors which was included in Local Bylaw on Management of Orderliness, Beautification, and Comfort of the City. In this bylaw, the problem of street vendors is addressed by eviction and sometimes by relocation.

After the bylaw had been implemented for 6 years, the City Government of Bandung realized that the policy of eviction and relocation of street vendors had not been effective in settling the problem of street vendors. It was marked by the thriving of street vendors in public places. The government then replaced the policy of eviction and relocation with the policy of arrangement and fostering of street vendors.

This policy includes the spatial arrangement of street vendors which divide Bandung into three zones, as follows

1. Red Zone is locations in Bandung where street vendors are forbidden to operate.

2. Yellow Zone is locations which can be opened and closed for the operation of street vendors based on time and places.

3. Green Zone is locations where street vendors are allowed to operate every day.

Hence, there is a fundamental change in the policy on street vendors in Bandung before and after 2011. The change relates to the paradigm on street vendors that at first were considered as illegal business and the disturber of Orderliness, Beautification, and Comfort become business persons of the informal sector. This change makes street vendors have the legal status and they are recognized by the city government and therefore they have the right to obtain various kinds of aids, such as financing facilities and business equipment. Substantially, Bylaw Perda No 4 Tahun 2011 is also a holistic regulation because it approaches street vendors by integrating the activities of planning, arranging, fostering, controlling, and law enforcement.

\subsection{The strategy of Street Vendors in Facing Eviction and Relocation Policies}

The form of daily resistance commonly is used by street vendors in the face of policy controlling and relocation is using Gossip. The phrases such as "Sucks the government (pemerintah tea pikasebeleun)", "the government don't care to the poor "the government only care to the industries / businessman, become the dissatisfaction form of the policy controlling of the street vendor.

The other strategy is playing "cat and mouse "(fooling around) with the authority, they didn't trade when the authority around but they still exist when there is no authority. Although this tactics is pretty much effective, but some street vendors admitted that they are tired with this condition. Some of them were then try to be friends with an apparatus. Some of street vendors try to become "friend "with the apparatus, give them some "money "to get an information about the next eviction or relocation plan. The information usually is sent by serial SMS that content ", tomorrow you will take holiday, there is an operation "This relationship is viewed as an effective action, the apparatus get an extra "money" and street vendor have time to rearrange the stall to avoid the eviction or relocation operation. The amount of money deposited is actually various depend upon an agreement between street vendors and "the apparatus", and so with the payment, it can delivery daily or weekly or even monthly. This matter is caused problems by themselves in government official's city. Some of the apparatus stand firm against the street vendors but the others collect money from street vendors every day or week and promises them freedom to trade (Ramli, 1992: 32).

The eviction and relocation plan is not actually leaked in to the street vendor. At certain times, their goods is taken away and transported in to apparatus vehicles. All informants researchers have had taken their goods and forced to deal with apparatus to regain their goods. To take back their goods, street vendors have to spend a number of ransom. Some of street vendors choose have to go to mild trial criminal act to get back their goods. 
The other tactics that usually use to face the eviction and relocation policy are:

1. Arguing with the officials. They usually argue with the officials, questioning the legal ground, solution, et cetera, when their wares were confiscated.

2. Provoking the apparatus. During the operation of eviction street vendors often uttered some words which caused the officials' anger so the operation ended in a riot.

3. Physically fighting the officials. Fighting is the resistance at the extreme level and it often claimed victims, both from the street vendors and the officials.

4. Cooperating with the officials in order to obtain information on the eviction plan and in return they gave bribes. It was carefully conducted considering not all officials were willing to cooperate.

5. Redeeming their wares. If their wares were confiscated by the officials, the street vendors did not reluctantly pay an amount of money to get their wares back.

6. Obeying. It was conducted by following the relocation program, but if they found few buyers there, the street vendors would return to their initial places.

When the government intensive does the eviction and relocation, street vendors begins to given thought about how to strengthen the line. Although is not a formal organization, at the time they started to do more often activities that involve many members such as gathering family, sports, touring motor, and others. This activity is coordinated by senior street vendors who later became an organization street vendors. This organization is a vessel to build relationship and sharing value of kinship among street vendors.

To face pressure government, the organization of street vendors has joined with the big street vendor's organizations or public organization. Besides of that, the organization street vendors has developed the network with NGO, the university student organization, and law aid institutions. This network made their more knowledgeable about the municipal and learn about negotiation technique with the government. So if they will be an eviction or relocated, they will argue and asked the legal formal and try to seek the solutions about how they managed their income sustain. If their goods have taken away by apparatus, NGOS and university students were usually provide assistance advocacy. When it started intensive, they do not hesitate to do a demonstration and usually, this way is effective to reduce the intensity of the rearrangement and relocation.

Some of the individual resistances forms were also conducted in collective resistances, such as fighting and cooperating with the officials. However, the resistances were conducted through planning and coordinating process among the street vendors so they had a stronger position.

1. Arguing

The arguing done by the organization of street vendors was supported by their sufficient knowledge of the problem of street vendors. It cannot be separated from the involvement of the people who had sufficient knowledge of the problem, for example, street vendor organization which included law and economy experts in their leadership. Therefore, in responding to the policy of eviction, for example, they did not only refuse it but also asked for a solution from the city government. Similarly, in responding to the policy of relocation, they argued about the places for relocation, not the policy itself.

2. Fighting

They committed fighting only when the organization of street vendors viewed the officials had committed a cruel and violent act. As the government's attitude towards street vendors became more persuasive, it became rarely committed.

3. Cooperating with the apparatus

The organization of street vendor collected dues from its members, which was then set aside for paying "coordination money" to the apparatus. In this way, it was expected that the members would be free from the eviction operation. The apparatus were usually chosen based on the friendship they had established before. As for the organization of street vendors which did not have a connection with the apparatus, they were usually affiliated with mass organizations. 
Apart from three forms of resistance above street vendors also committed other forms of resistance, which were relatively difficult to carry out individually, as follows:

1. Assistance and advocacy for the evicted street vendors by the organization of street vendors with the help of legal activists.

2. Staging a demonstration to protest the eviction, relocation and policies considered not accommodating the interest of street vendors. Demonstration was held by planning the issues to bring forward, how it would be staged (venues and time), symbols that would be used and the funding for the activities.

\subsection{The Strategy of Street Vendors in Facing Arrangement and Fostering Policy}

The changing of Paradigm street vendors policy from eviction and relocate paradigm to the arrangement and fostering paradigm has changed tactics and strategies street vendors in facing government policy. In the past, tactics, and strategies street vendors are more directed to the resistances form. But this time the street vendors strategy is more cooperation and negotiations. The resistances form took place if the negotiation faces the deadlock situation. Some of the street vendor's strategy in facing the arrangement and development of government policy are:

Some of strategy that has done by street vendors in facing government policy namely:

1. Urging the government to implement local bylaws which accommodate the interest of sidewalk vendors, for example, allocation of $10 \%$ of the space of modern shopping centers for micro, small and medium enterprises and to take measures against street vendors that did not comply with characteristics stipulated by Bylaw Perda No 4 Tahun 2011, that is, motorized street vendors and street vendors who sell goods that do not comply with provisions of the bylaw.

2. Encouraging the government to revise subject matters of the bylaw considered not accommodating the interest of street vendors, among other things, zonation system, a fine for buyers and imposition of resident identification cards of Bandung City.

3. Negotiating the places for relocation which match the characteristics of street vendors with sufficient access and infrastructures, among other things, by utilizing unused buildings and purchasing new lands.

4. Opening the access to financing aids, both to the government and banking institutions, conducted through direct negotiations with the city government and utilization of the established informal network.

5. Entering the formal political channel, that is, by becoming a legislator. During the process, certainly political transaction occurred, in which, the leader of street vendors was appointed as a candidate legislator and in return street vendors would vote for the political party.

Thus, strategy street vendors in facing government policy have been done through various strategies such as resistances, negotiation, and cooperation. The strategy has taken by street vendors indicates that street vendors are an agents or subject/actor with the ability to use their power that affect city government or other agents. This is relevant with Foucault (1978), that individuals are always experience the situation and perform the power simultaneously. The individuals are not only a moving and submissive target of power, but individuals also is always an element of the power disclosure, medium of power and not the point of the implication of power. Hence are inherently in social intercourse between the actually there are elements competition, contestant, resistance and also the consensus, negotiations, and cooperation.

\section{Conclusion}

Strategies of street vendors in facing public policy were carried out through disguised and open ways. These strategies were continuously changing, adjusted to the resources they owned or they could access and the city government's attitude towards street vendors. When street vendors thought they had sufficient resources 
(knowledge, internal unity, and supports from other institutions), they would stage an open resistance, such as arguing, fighting and staging demonstration. On the contrary, when street vendors thought they were in a weak position, they would make a disguised resistance, such as gossiping, disappearing at the time of eviction and returning after it had finished and pretending to obey the officials.

In this street vendors' resistance, the role of the organization of street vendors is thought to be important. At least, there are two important roles of the organization of street vendors, i.e.: 1) uniting the strength of street vendors so that they have a higher bargaining position than the city government 2) making the resistance more varied considering there are strategies that can be carried out individually, such as staging demonstration, opening the access to banking institutions, and entering the formal political channel. Nevertheless, there is an assumption that the organization of street vendors has taken advantage of the presence of street vendors by collecting membership dues. It has brought about internal conflict among sidewalk vendors, which usually ended in the exit of some street vendors from the organization and then they founded a new organization.

Other factors which also affected the strategies of street vendors were the city government's policy and the way they implemented the policy. When the policy of the government was dominated by the eviction, street vendors would choose to play cat and mouse, arguing, bribing the officials, and redeeming the confiscated wares. Strategies of fighting and staging demonstration were carried out when the city government was considered to ignore their aspiration. Meanwhile, when the policy of the city government was directed towards the program of fostering and arrangement of street vendors, they preferred dialogues and negotiation in order to open the access as wide as possible to obtain the aid from the city government. This condition indicates that street vendors' strategies, whether they are in the forms of resistance, negotiation, and accommodation, play the same important role in struggling for the interest of sidewalk vendors.

\section{References}

Abu- Lughod, L. (1990). The romance of resistance: Tracing transformations of power through Bedouin women. American ethnologist, 17(1), 41-55.

Cheater, A. (1999). "Power in the Postmodern Era." in Angela Cheater (Ed). The Anthropology of Power: Empowerment and Disempowerment in Changing Structure (London \& New York: Routledge. Hal. 1-12.)

Firdausy, C.M. (1995). Pengembangan Sektor Informal Pedagang Kaki Lima di Perkotaan. [ Development of the Informal Sector in Urban Street Vendors. Jakarta]. Jakarta: Dewan Riset Nasional dan Bappenas bekerja sama dengan Puslitbang Ekonomi dan Pembangunan

Foucault, M. (1978). Power/Knowledge: Selected Interview and Other Writing 1972-1977. London: The Harvester Press, Sussex

Hansen, H. P. (1999). "Patients' Badies and Discourses of Power.” In Chris Shore \& Susan Wright (Ed). Anthropology of Policy: Critical Perspective on Governace and Power. London \& New York: Routledge

Manning, C., \& Effendi, T. N. (1991). Urbanisasi, pengangguran dan sektor informal di kota. Diterbitkan untuk Yayasan Obor Indonesia dan Pusat Penelitian dan Studi Kependudukan UGM [oleh] Gramedia.

Maneepong, C., \& Walsh, J. C. (2013). A new generation of Bangkok Street vendors: Economic crisis as opportunity and threat. Cities, 34, 37-43.

McGee, T. (1973). Peasants in the cities: a paradox, a paradox, a most ingenious paradox. Human Organization, 32(2), $135-142$

Rachbini D.J \& A. Hamid. (1994). Ekonomi Informal Perkotaan Gejala Involusi Gelombang Kedua. Jakarta :LP3S

Ramli, R. (1992), Sektor Informal Perkotaan: Pedagang Kaki Lima di Jakarta. [Urban Informal Sector: Street Vendor in Jakarta]. Ind-Hill Co, Jakarta

Sethuraman, S.V. 1974. Urbanization and Employment in Jakarta. Geneva:ILO World Programme Research

Scott, J. C. (2000). Weapon of The Weak. Jakarta: Yayasan Obor Indonesia

Scott, J. C. (2008). Everyday forms of resistance. The Copenhagen Journal of Asian Studies, 4(1), 33.

Wirahadikusumah, M. (1991). Sektor Informal sebagai Bumper pada Masyarakat Kaptalis [Informal sector as a bumper on the Capitalist Society]. Prisma, 5, 31-39. 